\title{
PROPERTIUS 2.31: WHAT THE POET SAYS HE SAW
}

\section{J Steenkamp (North West University)}

Not only has Propertius 2.31 been used as a kind of artefact to reconstruct the Temple of Apollo on the Palatine, but it has also been used to show both that the poet was supporting the new ruler of Rome by eulogising his building projects and to show that the poet was anti-Augustan and expressed his opinions through subtly embedded allusions in the poem. This paper re-examines the artworks described in the poem, recent archaeological evidence and some of the poet's earlier work in order to understand to what extent the temple described in the poem corresponded to the physical temple in Rome; what kind of political message or social commentary the poem delivers, if any; and what this message says about the world of the poet.

The paper concludes that it is impossible to say how closely the description of the Temple of Apollo in the poem corresponded to the actual temple, partly because the poet could and probably did exploit the fact that his audience were familiar with the temple, such as emphasising certain features by omitting them. The poem does have a political message suggested by the detail of the artworks it describes, but this message is not anti-Augustan per se. Compared to the author's other early work, the poem professes strong pacifist sentiments, as is common to Roman elegy, but at no stage blames the princeps for the loss of human life which Propertius' poems deplores.

Much has been said about Propertius 2.31 and the Temple of Apollo on the Palatine. And, perhaps, too much has been deduced from the text about the temple and its contents. The aim of this paper is not to suggest new solutions to historical or archaeological questions or to propose a definitive answer to the presumed propaganda programme Augustus envisioned for the temple. It is an attempt to approach the text itself and see how much it actually says about the building, Augustus and the recently concluded civil war. Although this approach does not promise a completely new interpretation, it is hoped that it will delineate existing problems in a clearer light and open new avenues of inquiry. The paper considers the list of artworks described in the poem in an attempt to answer the following questions: why were these artworks included and why are other features of the temple not mentioned? Should the images described in the poem be interpreted as promulgating a political message? And if so, what exactly is this message? The 
paper will also venture an opinion on what kind of political and / or social commentary the poem promulgates.

There is an inherent danger in reading Propertius' description of the Temple of Apollo as a historical source. Firstly, the text of this poem, as is the case with almost the whole of the Propertian corpus, has been transmitted in a severely corrupt state. The specific supposed corruptions in 2.31 may have some impact on the reading of the poem, but it is believed that, since the discussion is limited to the artworks mentioned in the text, the core argument will not be affected, even if poems 2.31 and 2.32 are read as a single poem. ${ }^{1}$ Secondly, this short poem is our most complete contemporary source of the temple and its contents. The temple is briefly mentioned several times by Augustan poets and by historians, but is never described in any great detail. ${ }^{2}$ Unfortunately very little archaeological evidence remains of the temple. Despite this, or because of it, the topography of the temple has received much scholarly attention. Though it is now certain that the temple stood on the south-western slope of the Palatine, the location of the portico of the Danaids and any detail regarding the artworks that adorned the temple, are shrouded in uncertainty. ${ }^{3}$

There is also a danger in reading poetry in general (or any text) as referring to an objective reality. Since Derrida infamously remarked that nothing exists outside the text and since the excesses of generations of scholars who busied themselves with the perusal of Roman poetry in order to obtain biographical data, have been exposed, readers of Augustan poetry have been caught in a dilemma. Wilson (2009:173-174) has recently deplored this, still current, inconsistency in the reading of Augustan elegy. He explains that the erotic relationships in the poems are read with the assumption that the characters (Cynthia, Delia, Corinna, etc.) are fictitious as is the persona which the poet assumes in any given poem, but that the political relationships (with Maecenas, Octavian or Tullus) are assumed to be real and that these characters belong to the same empirical reality as the poet. The

1 I read poems 2.31 and 2.32 as two separate poems, though it makes little difference to the arguments presented here. I am following chiefly the interpretation of Hubbard 1984:218-297, who rejects most of the line transpositions suggested by Richardson 1977:301-308 and Camps 1967:56. The most recent arguments are discussed in Heyworth 2007:246-248 and Bowditch 2009:402 n.3. For the sake of clarity, the numbering is retained, as it occurs in most editions and specifically that of Camps.

2 A complete list of the sources can be compiled from the commentaries of Camps 1967:204, and Richardson 1977:302-305, as well as from Hekster \& Rich 2006:149. The most notable poetic sources are Horace Carm. 1.31, Tibullus 2.5, Vergil Aen. 8.704706 and 720-722 and Ovid Fast. 4.951-954, Ars am. 1.73-74 and Tr. 3.1.59-64.

3 Recent attempts to reconstruct the portico and other parts of the temple include that of Quenemoen, who gives a useful bibliography of excavation reports (2006:229-231 nn. 3 and 5-8), Zink 2008:47-63 and Zink \& Piening 2009:109-122. 
same, it seems, would apply to the Temple of Apollo in Propertius 2.31: there is no way to know how close to the 'real thing' Propertius' temple is.

An ecphrastic description, such as the one found in this poem, is a work of art in its own right and its relationship to the artwork to which it refers is almost always involved, multi-dimensional and complicated. The view adopted in this paper is that Propertius did not try to furnish his readers with a tourist guide type description of the temple and assumed that his audience was familiar with the building. Thus, it must be borne in mind that, just because certain aspects of the temple feature in the poem, it does not follow that these aspects were the most spectacular, most visible, famous or important aspects of the temple. In fact, it is just as likely that the poet exploited the fact that his readers were familiar with the temple, by subtly picking out some less conspicuous aspects and leaving out some better known features. ${ }^{4}$

Poem 2.31 starts by offering an excuse to Cynthia for being late, which the poet blames on his dallying at the opening of the portico of the Temple of Apollo on the Palatine (9 October $28 \mathrm{BC}$ ). ${ }^{5}$ The first half of the poem (lines 1-8), introduced by this excuse to Cynthia, describes, successively, the portico, the statues of Danaus and his daughters, a marble image of Apollo with lyre, and a group of four cattle sculpted by Myron. The second half of the poem, conspicuously marked by the introductory tum medium (line 9) mentions the white marble of the temple itself, an image of Sol on the fastigia and the temple doors with images of the Gauls being thrown off the cliffs of Parnassus and of the funeral of the Niobids. Lastly, another image of Apollo is described, this time dressed in a long robe, a description which reminds strongly of the famous Apollo Musagetes from the Vatican museum, flanked by images of Leto and Artemis.

The promotion of political themes (the opening of the temple) above the erotic priorities of the elegiac poet (visiting his girlfriend) has led interpreters to consider 2.31 a commissioned work. ${ }^{6}$ The publication of what is now known as Propertius' second book came after the poet's acceptance into the circle of Maecenas, and it contains topics which differ markedly from the subjective love

4 Omission of topographical features in an ecphrastic description of the city in Roman poetry is memorably exploited by Ovid in Tristia 3.1. The poetic point behind Ovid's omissions is discussed in detail by Huskey 2006:17-39.

5 Dio Cassius 53.1.3 informs us that the temple, its portico and the libraries were all inaugurated that year, if not on the very same day. The sources dating the opening of the temple are given by Last 1953:27-29.

6 Cairns 2006:340-341 for one, is sure of this and considers the poem an 'eulogy of Augustus from start to finish'. 
poetry of his first book. ${ }^{7}$ Entry into this circle meant being considered one of the more prominent poets in Rome and this afforded Propertius the opportunity and maybe even the obligation of writing about other poets and their poetry, as he does in 2.34. Lastly, one would imagine that membership of the elite society in Rome also entailed taking part in discussions of current political affairs with patrons and other wealthy citizens, hence the references to legislation (2.7), the imminent invasion of Parthia (2.14) and the new buildings on the Palatine (2.31).

The poem, though very visual, does not give a clear or detailed description of the artworks, and does not make it clear whether the images of Apollo are sculptures in the round or relief works. ${ }^{8}$ The integrity of the text has also been questioned on a crucial point: it has been suggested that lines 5-8 should be transposed to follow 16: such a transposition would imply that the poem refers to a single statue of Apollo.' However, reading Propertius as describing only one image, however, necessitates significant textual transpositions - see Richardson's commentary for the various suggestions - and is not supported by most scholars. ${ }^{10}$ Neither does such a reading seem necessary as there were doubtless a great number

7 The publication of Propertius' so-called second book is placed between 28 and 25 BC. Whether what we call Propertius' second book is in fact his second book, which seems increasingly unlikely, cf. Tarrant 2006:55-65 and Heyworth 2007:lxii, is not pertinent to the argument presented here. Propertius published this poem after his entry into Maecenas' circle as suggested by the numerous programmatic poems in the collection and whether this collection consisted of one or two books, poem 2.31 certainly dates from a stage in the author's career when his poetry started to include themes of national political interest.

8 Most commentators, plausibly, identify the images of Apollo described in lines 5-6 and 15-16 as statues (Butler \& Barber 1933:247, Last 1953:27-29, Camps 1967:205, Richardson 1977:303 and Newman 1997:85). Although Pliny NH 36.25 places the famous Apollo Citharoedus at the Palatine temple of Apollo, there is no indication that the images of Apollo described by Propertius are in fact statues. The term 'image' is used here in order to include also relief work, mosaics and wall paintings, which would surely also have been present in and around the temple.

$9 \quad$ So Butler \& Barber 1933:247-248. Heyworth 1994:59 proposes that a lacuna be posited before line 5 . This would spoil the symmetry around line 9 , where the temple itself is described as 'rising up in the middle' in the centre of the poem, i.e. the first line of the second half of the poem, but such a structural consideration does not seem enough reason to completely discard Heyworth's suggestion.

10 The most important arguments for more than one image of Apollo are Last 1953:27-29, who interprets Propertius' lines to support two images of Apollo in the temple precinct. Babcock 1967:189-194 also supports two as does Kellum 1982:68-74, quoted by Roccos 1989:572, who argues for three images of Apollo in the Temple precinct. 
of images of the god in and around his temple and there is no apparent reason why Propertius could not describe more than one. ${ }^{11}$

The order in which the artworks are presented seems to be dictated by an imaginary movement towards and into the temple (Last 1953:28-29 and Richardson 1977:302). First comes the portico, visible from afar, then the statues of the Danaids which one will see as a group from a reasonable distance and then, on coming closer, one will be able to discern the image of Danaus among them. The image of Apollo and the artwork of Myron, presumably, also stand outside the temple under the portico or between the portico and the temple, because the temple is described as rising up in the centre in line 9. Looking at the temple the poet's eyes are first drawn to the sculpture on the fastigia above and, on coming closer, he sees the doors and then the detail of the images carved on them. The deinde that introduces the final distich leads us to believe that this image of Apollo between his mother and sister stands beyond the ivory doors, inside the temple.

The poet prefers to omit some features of the temple which seem to be important, maybe even crucially important. Most intriguing is the omission of the famous Greek and Roman libraries, which we know were situated at the temple and were large enough to accommodate meetings of the senate. ${ }^{12}$ There are also a number of artworks mentioned by other poets and historians not mentioned by Propertius. Unfortunately so little is known about the temple from other sources that it is impossible to say to what extent Propertius exploited the omission of wellknown works for poetic reasons. ${ }^{13}$

Since the poet had a huge number of artworks from which to select images for the poem and assuming that he carefully selected (and deselected) the artworks that feature in the poem, it seems worthwhile to take a closer look at the selection criteria the poet employed in his selection. It might be suggested that some of the features of the temple were so spectacular or famous that they simply could not be

11 For multiple images of divinities in other sanctuaries see Roccos 1989:572-573 who quotes Ridgway: at least 30 statues of Apollo at Delphi (1984:38); 42 statues of Zeus at Olympia (1984:40); 11 statues of Athena on the Acropolis in Athens (1984:59). Finally, Pausanias 1.3.4 mentions three statues of Apollo in the Agora temple.

12 For the libraries, see CIL 6.5188, 5189 and 5884, their size, see Suet. Aug. 29, Ov. Tr. 3.1.63 and Tac. Ann. 2.37. For modern discussions see Dix 1994:282-292 for the extent to which these libraries were public, Horsfall 1993:58-67 on the influence these libraries had on Augustan and post-Augustan poets and Thompson 1980:335-339 on the Palatine temple complex as meeting place of the senate. The Sibylline books were probably brought only later from the temple of Jupiter on the Capitol and placed beneath the pedestal of the statue of Apollo. Miller 2009:240 n.118, makes a convincing case for 19 $\mathrm{BC}$ as a terminus ad quem. See among others Suet. Aug. 29; Tib. 2.5.17; Verg. Aen. 6.72 and Serv. ad loc.

13 Welch 2005:91-92 lists some more artworks believed to have been at the temple. 
left out. Or, from a pragmatic perspective, the author needed to establish a starting point, an aspect of the temple sufficiently conspicuous as to draw the audience 'into' the description of the temple which is to follow. Secondly, to some extent, the selection must also have been governed by the narrative strategy of movement towards the temple. But the most significant criterion for the selection of specific artworks seems to be the poetic agenda of the subtext.

Only the main building of the temple, its gilded decorations ${ }^{14}$ and whiteness (line 9), ${ }^{15}$ as well as the statues of the Danaids, can with any certainty be regarded as features of the temple so famous or conspicuous, that the poet could not leave them out. The white marble of the temple is also specifically mentioned by Vergil (Aeneid 8.720) and Ovid (Tristia 3.1.60) and the Danaids feature notably in Ovid (Amores 2.2.4, Ars Amatoria 1.74 and Tristia 3.1.62). ${ }^{16}$ The marble images of Apollo (lines 5-6 and 15-16) were most probably two of many and there is no way of showing that the images of Propertius' poem are in fact the famous statues mentioned in other sources. The cattle sculpted by Myron, though they were undoubtedly masterpieces, are not mentioned in other sources and, though Pliny (Naturalis Historia 36.11-3) mentions works by Bupalus and Athenis on the fastigia of the temple, he does not mention the chariot of Sol.

Similarly the selection of artworks by the poet cannot be wholly ascribed to the narrative strategy of imaging a gradual approach to the temple. One can easily imagine that the golden or gilded decorations on the pediment of the temple were visible from afar and the portico obviously comes into view before one can discern the detail on the doors. However, being able to choose from so many artworks in and around the temple and having the freedom to focus on any detail, the constrictions of the poet's narrative strategy cannot be considered a main indicator of the criteria for the inclusion of certain artworks.

The poet seems to have selected the artworks described in the poem mainly if not exclusively, according to a poetic agenda. As one would expect, almost all the artworks selected by the poet are linked, more or less directly, to Apollo after all, the temple was indeed dedicated to Apollo. The only exception is the statues of the Danaids, whose myth cannot easily be linked to the god; this point

14 Archaeological evidence now supports this description. Zink \& Piening 2009:113 showed that some of the decorations on the capitals were gilded.

15 Carrara marble was used, Richardson 1977:303 informs us, citing Servius ad Aen. 8.720. Most of the surfaces of the temple seem to have been left unpainted (Zink \& Piening 2009:114 n. 7).

16 The three references to the Danaids at the temple by Ovid are discussed by Barchiesi 2005:284, where he explains how the same image of the Danaids and their father in front of the temple, is used by Ovid to convey different kinds of messages in the three books. 
will be discussed below. Apollo features most conspicuously as god of music and song (lines 5-6 and 15-16), but it would be an oversimplification to say that the poet's eye catches these images of Apollo, because his glance naturally follows that which is important to him. Firstly, besides the images of Apollo, various other artworks are also described focussing on other qualities of Apollo and myths associated with him. Secondly, Octavian is conspicuously associated with the temple in the first couplet of the poem. ${ }^{17}$ The question is whether the selection of artworks Propertius chose to describe is in anyway significant - after all they represent only a few pieces of what must have been a vast collection. ${ }^{18}$ The paper will argue that the specific attributes of the god to which the poet draws attention and various aspects of the artworks, which the poet singles out for special mention — whether explicitly stated or implied — progressively build a subtext of social comment.

The artworks that dominate the description of the temple are two images of Apollo (lines 5-6 and 15-16):

\section{hic equidem Phoebo visus mihi pulchrior ipso marmoreus tacita carmen hiare lyra; \\ deinde inter matrem deus ipse interque sororem Pythius in longa carmina veste sonat.}

Here a marble image with mouth wide open in song to a silent lyre seemed to me even more beautiful than Phoebus himself.

Next the god himself, between his mother and sister, Pythius, in flowing robes, pouring forth songs.

Pliny (Naturalis Historia 36.25) informs us that a famous statue of Apollo Citharoedus by Scopas stood in the temple, but it is impossible to ascertain whether Propertius refers to this statue. ${ }^{19}$ In fact, from the text it is impossible to infer that these images are statues at all and not relief work. The second image of

17 Octavian is here referred to as 'Caesar' (1. 2) as elsewhere in Propertius. The temple's specific association with the battle at Actium is at the very least not clear and possibly absent, as will be argued below, the temple was originally avowed by Octavian in 36 BC after his campaign against Sextus Pompeius.

18 For discussions of the artworks excavated at the site of the temple see chiefly Zanker 1988:passim and Gurval 1995:111-136; more recently Hekster \& Rich 2006 especially the excavation reports in note 1 and the secondary sources in note 3 and Miller 2009:186-191.

19 As Camps 1967:205 and Miller 2009:188-189 assume. 
Apollo seems to be a free standing statue in a group as, according to Pliny (Naturalis Historia 36.24 and 32) an Apollo statue stood in the temple and was flanked by a Leto and an Artemis by Cephisodotus and Timotheus respectively. ${ }^{20}$

Though these images overtly describe the god's musical attributes, both also display the god's darker aspects just below the surface. Heyworth (1994:57-58) has seen in the description of the first Apollo (lines 5-6) an intertextual reference to Callimachus Hymn 2.24:

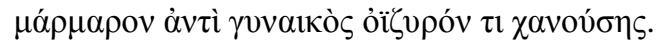

a marble rock, like a woman gaping out some sorrowful sound.

In Callimachus the marble image refers to Niobe, who suffered the wrath of a vengeful Apollo, and Propertius would refer to this same myth a few lines later in 2.31. ${ }^{21}$ Likewise, the epithet Pythius, applied to the Apollo featuring in the final lines, though a common designation of the god, inevitably conjures up associations with the slaying of Python and his acquisition of the sanctuary at Delphi. ${ }^{22}$

Apollo is indirectly linked to the cattle of Myron (lines 7-8) and to the chariot of the sun on the roof (line 11). By the first century BC Apollo's association with the sun was already well established ${ }^{23}$ and the description four cattle sculpted by Myron, the $5^{\text {th }}$ century Attic sculptor who was famous for his work on animals (Pliny, Naturalis Historia 34.57), leads the mind to the god's association with herds. Apollo famously tended cattle in Pieria, which was stolen by the infant Hermes (Homeric hymn to Hermes); the Iliad (21.450-452) mentions that Zeus commanded Apollo to guard the cattle of Laomedon and especially the story of Apollo tending the flocks of Admetus at Pherae on the banks of the river Amphrysus in Thessaly becomes more prominent in later writers. ${ }^{24}$ Though this myth of Apollo seems innocent enough now, Roman viewers would surely have

20 A panel from Sorrento, also displaying Apollo between Leto and Artemis forms the basis of the important study of Apollo statues during the Augustan age by Roccos 1989:571-588.

21 More has been made of this intertextual link to Callimachus, see Barchiesi 2005:284285 and Miller 2009:202-204.

22 The reference to Apollo's usurpation of the sanctuary at Delphi also suggests a reference to Callimachus' Hymn 4 (to Delos) especially line 91 and the Homeric hymn 3 (1l. 370375), where the epithet Pythius is applied to the god.

23 Graf 2009:151-153 puts the identification of Apollo with the sun as far back as the fifth century. For absorptions and association of cults and especially Apollo's absorptions of Sol's functions, see the discussion by Solomon 1994:42-43.

24 Cf. Callim. Hymn 2.47-49, Apollod. 1.9.15, Tib. 2.3.11 and especially Verg. Geo. 3.2. 
been aware that Apollo was sentenced to serve a mortal because he killed Zeus' Cyclopes. ${ }^{25}$

The decorations on the temple doors also depict myths involving Apollo. We are told by the poet, the one door 'mourned' the (death) of the Gauls thrown from the cliffs of Parnassus and the other 'mourned' the deaths of the Niobids. Propertius is our only source for these artworks and, although there is no reason to doubt that these images appeared on the temple doors, there is also no way of knowing that they were the only or even most conspicuous artworks there. The presence of Apollo is strongly felt in the events depicted. He features, with his sister Artemis, in the case of the Niobids, as divine avenger and punisher of hubris and in defeating the Gauls, he is cast in his role as protector god, especially of his oracle at Delphi.

The story of Apollo and Artemis slaying the Niobids is related by various sources. The earliest, Homer (Iliad 24.602-609), says there were six sons and six daughters born to Niobe and that they were killed because their mother compared herself with Leto and boasted that she had borne more children. In later tradition, Ovid (Metamorphoses 6.146-312) fixes the number of children on seven boys and seven girls, as do (Pseudo-)Apollodorus (Bibliotheca 3.5.6) and Diodorus Siculus (Bibliotheca Historica 4.74.3-4). Most versions concur that the tragedy was caused by Niobe's hubris. ${ }^{26}$ The defeat of the Gauls on the other door refers to the invasion of 279 BC. ${ }^{27}$ Pausanias (10.23.1-9) relates how, when the Gallic forces were camping at Delphi, portents were sent by the god. He notes specifically that the ground shook for the whole day and that there was continuous thunder and lightning, which not only prevented the Gauls from hearing orders, but also set those who were struck on fire. In the evening, he continues, there was a severe frost and snow and great rocks broke from Parnassus and fell on the Gauls.

Of the artworks described in 2.31 only that of the Danaids is not obviously linked to Apollo or any myth associated with him. Tradition has left us a great

25 (Pseudo-)Apollodorus (3.10.4) relates the myth: Zeus killed Asclepius with a thunderbolt in order to prevent humans from living too long. Apollo then took illdirected revenge on the Cyclopes, who manufactured Zeus' thunderbolts, by killing them. Zeus threatened to incarcerate Apollo in Tartarus, but, through the intercession of Apollo's mother Leto, reduced the sentence to a year's hard labour with Admetus.

26 Propertius 2.20.7-8 applies the adjective superba to Niobe and, incidentally, also furnishes her with six sons and six daughters. Hyginus (Fab. 9) adds that besides her boast of having more children than the Titaness, she also spoke contemptuously of Artemis and Apollo, because she wore a man's attire and he wore his hair long and dressed in a woman's gown.

27 The ancient sources are reviewed in Champion 1995:213-220, but see also Liv. 38.16 and Paus. 1.4.1 and 1.10.19-23 as well as Cic. De Div. 1.81 where the events are mentioned in passing in a discussion of 'apparitions'. 
number of variants of the myth of the Danaids and details must be pieced together from various sources. The salient points are that there was some form of conflict between two brothers, Danaus and Aegyptus, each with fifty children. The result of the conflict was that the fifty daughters of Danaus were forced to marry their fifty cousins, the Aegyptioi. On their wedding night, all except Hypermnestra killed their husbands. Later they are eternally punished in the Underworld by having to carry water in jars perforated like sieves. ${ }^{28}$

The illustration of this myth is an apparently strange choice of decoration for this temple. Horace (Carmina 3.11.25-52) tells of the Danaids, already in the Underworld being punished for impiety and their punishment is also briefly mentioned in Propertius (2.1.67 and 4.11.27-28.) Not only is theirs a story of family strife with violence being done within a family, and deceit, but they were judged in the Underworld and found guilty of impiety. Richardson (1977:302) assures us that there is 'no special connexion between the Danaids and Apollo', but this is not completely correct. Graves (1960:200-201 and 203 n. 4) points to the text of Pausanias 2.19.3-4, which informs us that when Danaus arrived in Argos the king, Gelanor (the son of Sthenelas), ${ }^{29}$ would not cede the throne. However, a wolf came down from the hills and killed the leading bull of a herd of cattle and this was seen as an omen that, if Danaus was opposed, he would take the throne by force. Hence, Gelanor decided to resign the throne and Danaus, convinced that the wolf was Apollo in disguise, subsequently dedicated a shrine at Argos to Apollo Lukeios. $^{30}$

Besides Apollo, who can be associated with all the artworks described by the poet and is the most conspicuous common denominator, another aspect of the description stands out. The specific mention of the columns of 'Punic marble' yellow or red in colour (Camps 1967:205) - adds to the visual impact of the poem, but Richardson's (1977:303) contention that the adjective seems to be no more than a way of saying that the marble was from Africa, is somewhat misleading. This reference to Africa is repeated in the adjective Libyci applied to the ivory of the temple doors and the story of the Danaids is also linked to Africa. The explicit mentions of Africa and the implicit mention of the Aegyptioi in juxtaposition with 'Great Caesar', evoke the memory of enemies of Rome that came from Africa.

Critics have seen various subtexts of social comment in the poem's description of the temple. The older interpretation that the poem 'does not make

28 See Gantz 1996:203-207 for variants of the myth and Keuls 1974:47-49 and 117-119 for a discussion of the Danaids on Roman monuments.

29 Aeschylus Suppliants gives Pelasgus as king of Argos at that time.

30 For a discussion of this myth from a different vantage point, see Graf 2009:120-122. 
any reference to [the artworks'] political and religious significance' (Syndicus 2006: 308) is still in circulation, while the more recent view that the poem abounds in political allusions (Bowditch 2009:411) is heard more and more often. The issue of the temple's association with the victory at Actium has also come under the spotlight and general consensus has not been reached. The issues regarding the interpretation of Propertius 2.31 can be reduced to the following: (1) To what extent did the Temple of Apollo on the Palatine - this is, the physical temple on the Palatine referred to by the text - commemorate the victory at Actium? And to what extent was the Temple of Apollo on the Palatine associated with Actium in the minds of the poets? (2) Is Propertius 2.31 eulogising the new princeps or through subtle allusions criticising him? Or is the poem delivering social commentary on a different topic?

Opinions are divided as to how closely, at this stage, the Apollo of the Palatine temple was associated with the victory at Actium, chiefly because of a dearth of physical evidence. The artworks from the temple, as far as they have survived, as well as numismatic evidence are discussed by Zanker and Gurval. Neither could show direct evidence of any link between the Temple of Apollo and Apollo Actius and, in considering the circumstantial evidence, they hold opposing opinions. Zanker (1988:85) contends that there had been a statue specifically of Apollo Actius in the complex near the statues of the Danaids and associates this statue with depictions of the god on a denarius (RIC $\left.{ }^{2} 365-6\right)$ which is clearly identified as Apollo Actius. ${ }^{31}$ Gurval, having studied the same coin, finds the identification with the temple dubious and suggests that Zanker might have followed claims made by editors of numismatic catalogues (Gurval 1995:125). ${ }^{32}$ Having studied the coin himself, he could not find any indication that the Apollo on the coin was in fact a depiction of a statue from the temple on the Palatine and it is hard to disagree with him on this point. He dismisses the idea that the temple of Apollo on the Palatine displayed any allusions to Actian Apollo on the basis that there exists no official cult titles or dedicatory inscriptions linking Apollo

31 The coin in question was issued by one of the moneyers from the collegium in Rome in 16 BC a certain Antistius Vetus, according to Butrica 2001:304, presumably the G. Antistius Vetus who was consul in $30 \mathrm{BC}$. The obverse reads 'IMP(erator) CAESAR AUGUST(us) TR(bunicia) POT(estate) IIX' and the reverse 'shows the male god in a long robe, standing on a low platform ornamented with what is probably three naval prows flanked by two anchors'. The god holds a patera in his right hand and a lyre in his left and the legend above and below the altar reads 'APOLLINI ACTIO' (Gurval 1995:285). Propertius 2.31 makes no mention of the decorated platform or the patera in Apollo's hand.

32 Gurval 1995:285-286 nn. 20-22 cites the numismatic catalogues. Interpretations of this coin and guesses as to which statue of Apollo it depicts are listed by Miller 2009:201 n. 27. 
Citharoedus (which appears in the temple) and Apollo Actius; archaeological evidence proposed for such a link is inconclusive and historical documents record no steps taken by Augustus to embellish the memory of Actium at the dedication of the temple (Gurval 1995:126 and 131). ${ }^{33}$

More recently Welch (2005:85-89) summarised the evidence and concurred with Zanker. She cites, as evidence for an association between the temple and Actium: (1) 'the preponderance of African materials used in the temple complex'; (2) the dramatisement of 'Cleopatra's eternal shame' symbolised by the Danaids; (3) the "possibility that the figure of Apollo in the portico of the Danaids was styled "Apollo of Actium"'; (4) the imagery on the ivory doors and (5) the remains of a terra-cotta relief depicting Apollo and Hercules struggling over the Delphic tripod, found at the site. ${ }^{34}$ However, the 'preponderance of African materials' is prominent only in Propertius' selective description. Materials from many parts of the known world were used in the temple and, as Welch concedes, the use of materials from exotic locations does not necessarily point to Actium. Welch also concedes that the symbolism of the Danaid statues may be interpreted in various, contradictory ways and that the imagery of the temple in general 'resists stable interpretation' ${ }^{35}$ In the images of the murderous Danaids allusions to both civil war in general (the murder of relatives) and to the war against Cleopatra and Egypt specifically have be seen. ${ }^{36}$ Exactly how the analogy works is unclear. Either Antonius or Cleopatra may be symbolised by the Danaids: the former was, like the Danaids, punished for crimes and the latter, like the Danaids, was the undoing of her husband. Alternatively the Danaids might represent the Romans and their conflict with the forces from Egypt, or the sons of Aegyptus. ${ }^{37}$

Gurval argues that any memorial of the battle of Actium in the City, however hidden, would seem to be incongruent with Octavian's political agenda at the time. ${ }^{38} \mathrm{By} 28 \mathrm{BC}$, the new master of Rome was not in a secure position at all..$^{39}$

33 This, however, is not to say that Octavian did not commemorate his victory at Actium though temples and statues in cities far away from Rome - most notably at Actium, Nicopolis and Alexandria. Butrica 2001:301 makes a strong case that 'the distinction between [Apollo] Actius and [Apollo] Leucadius ... is without foundation'. Apollo Leucadius (Prop. 3.11.69-70) is the Apollo whose temple stood above the white cliffs at Leucas and was visible from the battle of Actium.

34 An image of the remains of a terra-cotta relief is reproduced in Zanker 1988:247.

35 In fact, the stability of the meaning of monuments in general has been questioned, cf. Miller 2009:205-206.

36 See Zanker 1988:85-89, Gurval 1995:124-126 and Welch 2005:85-89 above.

37 See especially Fowler 1991:30 criticising Lefèvre 1989.

38 Representations of the battle of Actium and references to the event have, however, been found in private houses and on tombs of, particularly, rich freedmen of the early $1^{\text {st }}$ century AD, see Kellum 2010. 
Rome was only beginning to recover from the civil conflict and Octavian went to great lengths to try and heal the schisms created by the war and to integrate citizens who supported Antonius into his administration. It is interesting to note that despite the 'Augustan programme', the restoration and reconstruction projects and the Augustan Age's fascination with its past, that no contemporary account of the details of the battle at Actium has survived. ${ }^{40}$

Finally, it must be mentioned that, the temple may have accrued its associations with the battle of Actium only a decade later. The temple, as Propertius saw it when he composed 2.31 - presumably on October $9^{\text {th }} 28 \mathrm{BC}-$ may not have been the finished article. Some of the important artworks mentioned in later texts, like Vergil's Aeneid 8, Propertius 4 and Pliny may have been added later. By 18 BC Octavian, then Augustus, was in a much stronger political position and could afford to mythologise his image to a greater extent by, for instance, adding artworks commemorating the victory at Actium to the collection in the temple.

Though overt allusions to Actium and the civil war may have been absent from the architecture and the artworks in the temple and Octavian might have wished to avoid reference to Actium in general and specifically in the artworks of the Palatine temple, this need not have prevented the poets, and indeed most viewers, from associating the temple with Actium. A cursory glance at the better known poetic texts in which the temple of Apollo on the Palatine features gives ample grounds for suspecting that this was the case in Augustan literature. In Horace and Propertius' earlier work the temple is mentioned in association with social comment or political messages. In Horace's Carmen 1.31 the poet dons the vates-persona, which was more political than the poeta-persona and in Propertius 2.31 magnus Caesar (referring to Octavian) appears in the second line. Though overt references to the battle of Actium are hard to find in these two poems, and are possibly absent, both Vergil and Propertius would later link the temple more

39 It seems now that the Octavian's so-called restoration of the Republic and resignation of his powers did not occur in one dramatic act during his seventh consulship (27 BC), following Cassius Dio (53.2), see also Syme 1939:307 and 313 and Gruen 2005:34-46, but was a processes that started at the beginning of $28 \mathrm{BC}$. For an updated history of the settlement of 28/27 BC in the light of recently discovered numismatic evidence, see Rich \& Williams 1999:188-212, which emphasises that Octavian's 'true aim of the settlement of 28-27 was to legitimise the new regime by obtaining public assent for it and casting it in republican guise' (204). The authenticity of the Leges et Iura aureus of Octavian, upon which much of Rich \& Williams' argument is based, has been all but confirmed by the discovery of a second coin of the same type in 2005, see Abdy \& Harling 2005.

40 The ancient sources, both contemporary and later, are usefully listed and discussed in Tarn 1931:173-199. 
directly to Actium. In Vergil's Aeneid (8.714-728) the image of Octavian sitting on the steps of the temple appears after a lengthy description of the victory at Actium and Propertius 4.6 professes to be an aetiology of this very temple, but consists mostly of a description of the events surrounding the battle of Actium.

The fact that Octavian cultivated a close bond with his patron deity and systematically exploited Apolline imagery to suit his own public image, strongly suggest that Propertius 2.31, in which various aspects of the god is a leitmotif, contains a political message. The nature and content of this message is, however, difficult to gauge. The poem is generally thought to be either pro-Augustan, celebrating the magnificence of the building programme, the new peace, etc., or anti-Augustan, that is, criticising the Augustan programme through focusing on subversive details in the mythological allusions of the artworks. In the conclusion of this paper I would like to suggest firstly, that the poem is not pro- or antiAugustus, but describes the master of Rome as multi-faceted and contradictory as, in fact, his patron deity was and secondly, that the poem is not about Actium per se, but about war in general and the deplorable loss of life associated with it.

Though it is true that the images of the musical Apollo are very conspicuous in the poem, the darker side of the god is also visible. Both the descriptions of musical Apollo also contain references to the other, violent Apollo: the first hides an intertextual allusion to Callimachus Hymn 2 where the wailing of Niobe is referred to and the second applies the epithet Pythius to the god, which also refers to an Apolline act of killing. Likewise, the myth of Apollo tending cattle, to which the Myron group alludes, refers indirectly to Apollo's slaying of the Cyclopes and the god's vengefulness is keenly felt in myths depicted on the two ivory door panels.

To interpret the prominence of the darker aspects of Apollo in the poem as anti-Augustan sentiment is tempting, but unfounded. The nod to 'Great Caesar' can hardly be construed as ironic. Just as the poet admires the great edifice in front of him, he indirectly recognises its author. A more sober interpretation is to see in Propertius' use of the multi-faceted image of Apollo a reflection of the multifaceted character of the new organization of Rome and to see in his references to loss in the images of the Danaids and the mourning temple doors, among other, no more than deprecation of the civil war.

Professing a pacifist approach is of course typical of the elegiac lover, but it seems that Propertius suffered the horrors of war personally and exceptionally keenly and this is reflected in his poetry. His first book, which consists almost exclusively of poems with amatory themes, is concluded, conspicuously, by two poems with references to civil war and events surrounding the siege of Perusia (poems 21 and 22). The siege of Perusia (41 BC), which has since become infamous for the cruelty displayed by Octavian to its town councillors, who were 
executed, must have weighed heavily on the mind of Propertius who, it would seem, grew up, if not in the town, then very close by it. ${ }^{41}$ Consequently, the poet had no reason to approve of the new princeps or the way by which he rose to power.

Propertius' second book opens with a recusatio, which also mentions several events from the civil war and here, too, the siege of Perusia is singled out, this time in a more subtle fashion. In the recusatio the poet explains that, if the Fates had granted him the power (line 17) he would not sing about ancient mythology, or the origins of Rome (lines 19-24) or even the Punic wars, but he would prefer the wars and political deeds (bellaque resque) of Octavian (lines 25-26). He continues to enumerate typical subjects he would describe (lines 27-34). With the exception of one, the events are related in chronological order: ${ }^{42}$ (1) the defeat of M. Antonius at Mutina (43 BC), (2) M. Antonius' defeat of Brutus and Cassius at Philippi (42 BC), (3) Octavian's war on and eventual defeat of Sextus Pompeius, son of Pompeius Magnus at Naulochus (38-36 BC), (4) the Perusine war against L. Antonius (41 BC) and (5) the Alexandrian war against the remaining forces of Cleopatra and Antonius just after Actium. What is striking about this enumeration is the single instance where the chronological sequence of events is disregarded. The Perusine war or siege definitely happened before hostilities between Sextus Pompeius and Octavian broke out, as any Roman of the time would know. Propertius also disregards chronological sequence for emphasis in the final description of the triumph of $29 \mathrm{BC}$, after the capture of Egypt. On lines 31-34 Nethercut (1971:413) remarks that Propertius implies a different order to the processions at the Triple Triumph of $29 \mathrm{BC}$ to the one we have from Dio Cassius (51.21.5-8) and makes the point that Propertius' 'promotion' of the Actian procession to last in the list, instead of on the middle day as Octavian had it, gives a clue to the latent intention of the poem.

In his earlier poetry, Books 1 and 2, when Propertius mentions the civil war, most often it is not the establishment of Octavian's rule or the birth of a new world order that is emphasised, but the loss of human life that is deplored. In both the final two poems of Book 1 - the only reference to the civil war in the book - and the opening poem of Book 2 the dead are mourned: sepulcra are found at Perusia (1.22.3) and civilia busta are found at Philippi (2.1.27). The same tendency is

${ }^{41}$ The events are related by Appian BC 5.5.38-39 and Dio Cassius 48.14.3. Modern historical discussions include Syme 1939:210-212, Nethercut 1971:413-416, Putnam 1976:93-123 and especially Stahl 1985:99-129 and, recently, Cairns 2006:46-54.

42 The identification of the events to which the poem refers is indebted to the commentary of Richardson 1977:212-214. 
found throughout Book 2, which mentions the civil war four times $-2.1 .19-34$, 2.15.41-8, 2.16.39-42 and 2.34.61-2. ${ }^{43}$

Almost without exception the references to the civil war in Book 2 focus on, or at least mention prominently, the victims and the dead. The reference to the civil war in 2.1.19-34 focuses on the victims: the 'civilian graveyard at Philippi', the 'overturned hearths of the ancient Etruscan gens' and the maimed Nile being dragged into the city. Likewise, 2.15.41-44 says, if everyone would live like the poet (that is, 'be incapacitated by too much wine'), there would be no wars and nec nostra Actiacum verteret ossa mare [our bones would not be turned by the Actian waves] and 2.16.37-38 reads: cerne ducem, modo qui fremitu complevit inani / Actia damnatis aequora militibus: [Consider the general who, lately, amid the futile commotion, filled the Ambracian gulf with doomed soldiers]. The general is M. Antonius, as the poem makes clear, but the point is that his defeat at Actium is cast as a fated waste of human life. Lastly, the mention of Actium in 2.34.61-62 is embedded in a reference to Vergil's Aeneid, which was in production at the time and is about Vergil's poem, rather than the civil war.

Actium features in 2.31 only if a reference to it is read into the symbolism of either the Danaid group, or the images on the temple doors. Nevertheless, these artworks too, dwell primarily on the loss of life, the victims of conflict and those who mourn their deaths. Propertius would deplore the loss of Roman lives in the civil war again in his poetry, and at least once (3.5) he makes it completely clear that he is not cut out to partake in or to sing about war and ascribes mankind's warlike character to a mistake made by Prometheus when he made the first human. ${ }^{44}$

Propertius would return to both Perusia and Actium in his fourth book. In 4.1.127-130 the poet returns to the confiscation of the land belonging to his family near Assisi and 4.6 is almost completely devoted to the battle of Actium. The political subtexts in these poems are however, not the same as in 2.31 , having been written under different circumstances and probably for different reasons. ${ }^{45}$ By 16 BC when Propertius' fourth book was completed, twenty-five years have elapsed since Perusia and many of the wounds left by the civil war have been heeled. By this time Propertius was a well established poet in Rome and has

43 Nethercut 1971:413-414 lists the four instances in Book 2 where he believes the battle of Actium is mentioned. He includes the first three instances from the list above, but includes 2.31 and omits 2.34.61-62. To be fair, 2.34.60-61 is really about Vergil's Aeneid 8, which mentions the battle of Actium.

44 The selections given in Sullivan 1976:54-75 make Propertius' opinion regarding war and especially the civil war quite clear. These extracts on their own, contra Sullivan, do not constitute proof that Propertius was anti-Augustan per se.

45 For a discussion of this aspect, see Cairns 2006:57-59. 
probably recovered much of his family's financial losses through his association with Maecenas.

Returning to the temple of Apollo on the Palatine and Propertius 2.31, some conclusions can be drawn. The temple itself, as far as can be gathered today, seems to have been a concatenation of artworks and symbolism, into which various subtexts could be read depending on the specific point of view or, as is the case in Propertius 2.31, the sequence in which they are viewed. Galinsky (1996:221-222) remarks that the artists working for Augustus on the temple were developing an 'imagery that involved experimentation and multiple meanings', because Augustan culture was characterised 'not by frigid homogeneity, but by plentiful tensions and contradictions'. Propertius' ecphrastic poem does exactly this and reading its 'message' through its unique point of view is extremely difficult, if not impossible, without a clear picture of the temple. However, judging by what is known of Propertius' other poetry and of his political context, it seems possible to say that his political 'message' is not subversive in the sense that it is anti-Augustan nor critical of the new princeps in that it opposes the new programme. In fact, it seems that Propertius is deploring the excesses of war and the suffering it causes in a way that is not too far removed from the pacifist sentiments found throughout Latin elegy.

The poem exploits the various contrasting aspects of Apollo, the patron deity of Octavian, in order to describe the complicated nature of the new administration of Rome. Octavian's unique position and the organisation of the new regime must have appeared bewilderingly complicated to the citizens of Rome, not only was the political programme of the princeps at this stage still illdefined (probably even in his own mind), but the Roman people still deeply felt the divisions caused by the civil war. The image of Apollo, a patron of the arts and a vengeful god, a bringer of pestilence as well as healer suited Propertius well as a symbol through which he could try to describe the world around him.

The ambivalent feelings expressed towards the new regime in 2.31, have been, hopefully, better delineated. The poet is favourably impressed by the building projects in Rome and is inspired by the artworks on public display. He is grateful for the peace that followed Actium and he no doubt looks forward to a time of relative peace in which the arts will flourish. But, in the same breath, the poet also remembers that these pleasures came at a price. While he and other citizens can enjoy the opening of the new temple, other Romans are mourning those who died in the civil war. Propertius is not a reactionary Republican wishing for the 'good old days', he seems even at this stage, prepared to sacrifice the comparatively greater political freedom afforded by the Republic, in order to enjoy the peace brought by Octavian under a more autocratic rule. 


\section{BIBLIOGRAPHY}

Abdy, R A \& Harling, N (2005). Two important new Roman coins. Numismatic Chronicle 165:175-178.

Babcock, C L 1967. Horace Carm. 1. 32 and the dedication of the temple of Apollo Palatinus. Classical Philology 62:189-194.

Barchiesi, A 2005. Learned eyes: Poets, viewers and image makers. In Galinsky, K 2005:281-305.

Bowditch, L 2009. Palatine Apollo and the imperial gaze: Propertius 2.31 and 2.32. American Journal of Philology 130:401-438.

Breed, B W, Damon, C \& Rossi, A (eds.) 2010. Citizens of discord: Rome and its civil wars. Oxford, Oxford University Press.

Butler, H E \& Barber E A 1933. The elegies of Propertius. Oxford, Clarendon Press.

Butrica, J L 2001. Apollo Actius, Apollo Leucadius: A false problem in Latin poetry. In Joyal 2001:289-311.

Cairns, F 2006. Sextus Propertius: The Augustan elegist. Cambridge, Cambridge University Press.

Champion, C 1995. The Soteria at Delphi: Aetolian propaganda in the epigraphical record. American Journal of Philology 116:213-220.

Camps, W A 1967. Propertius: Elegies Book II. Cambridge, Cambridge University Press.

Dix, T K 1994. 'Public libraries' in Ancient Rome: Ideology and reality. Libraries \& Culture 29:282-296.

Dominik, W J, Garthwaite, J \& Roche, P A (eds.) 2009. Writing politics in imperial Rome. Leiden, Brill.

Fowler, D P 1991. Narrate and describe: The problem of ekphrasis. Journal of Roman Studies 81:25-35.

Galinsky, K 1996. Augustan culture: An interpretive introduction. Princeton, Princeton University Press.

Galinsky, K (ed.) 2005. The Cambridge Companion to the age of Augustus. Cambridge, Cambridge University Press.

Gantz, T 1996 [1993]. Early Greek myth. Volume 1. Baltimore, Johns Hopkins Press.

Graf, F 2009. Apollo. London \& New York, Routledge.

Graves, R 1960 [1955]. Greek myths. Volume 1. Harmondsworth, Penguin.

Gruen, E S 2005. Augustus and the making of the Principate. In Galinsky (ed.) 2005:31-51.

Günther, H-C (ed.) 2006. Brill's Companion to Propertius. Leiden, Brill. 
Gurval, R A 1995. Actium and Augustus: The politics and emotions of civil war. Ann Arbor, University of Michigan Press.

Hekster, O \& Rich, J 2006. Octavian and the thunderbolt: The temple of Apollo Palatinus and Roman traditions of temple building. Classical Quarterly 56:149-168.

Heyworth, S J 1994. Some allusions to Callimachus in Latin poetry. Materiali $e$ discussioni per l'analisi dei testi classici 33:51-79.

Heyworth, S J 2007. Cynthia: A companion to the text of Propertius. Oxford, Oxford University Press.

Horsfall, N 1993. Empty shelves on the Palatine. Greece \& Rome 40:58-67.

Huskey, S J 2006. Ovid's (mis)guided tour of Rome: Some purposeful omissions in 'Tr.' 3.1. Classical Journal 102:17-39.

Hubbard, T K 1984. Art and vision in Propertius 2.31/32. Transactions of the American Philological Association 114:218-297.

Joyal, M (ed.) 2001. In Altum: Seventy-five years of Classical Studies in Newfoundland. St. John's, Memorial University of Newfoundland.

Kellum, B A 1982. Sculptural programs and propaganda in Augustan Rome (Diss. Harvard University).

Kellum, B A 2010. Representation and re-representation of the battle of Actium. In Breed et al. 2010:187-205.

Keuls, E 1974. The water carriers in Hades: A study in catharsis through toil in Classical Antiquity. Amsterdam, Adolf M. Hakkert.

Last, H 1953. The Tabula Hebana and Propertius II, 31. Journal of Roman Studies 43:27-29.

Lefèvre, E 1989. Das Bild-Programm des Apollo-Tempels auf dem Palatin. Konstanzer Althistoriche Vorträge und Forchungen, Konstanz, Xenia 24.

Miller, J F 2009. Apollo, Augustus and the poets. Cambridge, Cambridge University Press.

Nethercut, W R 1971. The ironic priest: Propertius' 'Roman Elegies' III. 1-5: Imitations of Horace and Vergil. American Journal of Philology 91:385407.

Newman, J K 1997. Augustan Propertius: The recapitulation of a genre. Spudasmata 63 Hildesheim, Georg Olms Verlag.

Putnam, M C J 1976. Propertius I.22: A poet's self-definition. Quaderni urbinati di cultura classica 23:93-123.

Quenemoen, C K 2006. The portico of the Danaids: A new reconstruction. American Journal of Archaeology 110:229-250.

Rich, J \& Williams, J H C 1999. LEGES ET IVRA P R RESTITVIT. A new aureus of Octavian and the settlement of 28-27 BC. Numismatic Chronicle 159:169-213. 
Richardson, L 1977. Propertius: Elegies, I-IV. Norman, University of Oklahoma Press.

Ridgway, B S 1984. Roman copies of Greek sculpture. Ann Arbor, University of Michigan Press.

Roccos, L J 1989. Apollo Palatinus: The Augustan Apollo on the Sorrento base. American Journal of Archaeology 93:571-588.

Solomon, J 1994. Apollo: Origins and influences. Tucson, University of Arizona Press.

Stahl, H-P 1985. Propertius. Love and war. Individual and state under Augustus. Berkeley, University of California Press.

Sullivan, J P 1976. Propertius: A critical introduction. Cambridge, Cambridge University Press.

Syme, R 1939. The Roman revolution. Oxford, Oxford University Press.

Syndicus, H P 2006. The Second Book. In Günther 2006:245-318.

Tarn, W W 1931. The battle of Actium. Journal of Roman Studies 21:173-199.

Tarrant, R 2006. Propertian textual criticism and editing. In Günther 2006: 45-65.

Thompson, D L 1980. The meetings of the Roman Senate on the Palatine. American Journal of Archaeology 85:335-339.

Welch, T S 2005. The elegiac cityscape: Propertius and the meaning of Roman monuments. Columbus, University of Ohio Press.

Wilson, M 2009. The politics of elegy: Propertius and Tibullus. In Dominik et al. 2009:171-202.

Zanker, P 1988. The power of images in the age of Augustus. Trans. A Shapiro. Jerome lectures, 16th ser. Ann Arbor, University of Michigan Press.

Zink, S 2008. Reconstructing the Palatine temple of Apollo: A case study in early Augustan temple design. Journal of Roman Archaeology 21:47-63.

Zink, S \& Piening, H 2009. Haec aurea templa: The Palatine temple of Apollo and its polychromy. Journal of Roman Archaeology 22:109-122. 